\title{
Interleukin 3 Receptor
}

National Cancer Institute

\section{Source}

National Cancer Institute. Interleukin 3 Receptor. NCI Thesaurus. Code C39273.

Heterodimeric human Interleukin 3 Receptor is composed of 378-aa 43-kDa (precursor) Interleukin 3 Receptor Alpha and GM-CSF/IL-3/IL-5 Receptor Common Beta-Chain. IL3RA is a type I membrane protein with a box 1 motif for JAK interaction/activation and a WSXWS motif for protein folding, intracellular transport, and cell-surface receptor binding. Receptor binding to IL3 depends on the signal transducing beta subunit, common to the high affinity IL3-, IL5- and GM-CSF receptors. ( $\mathrm{NCl})$ 